
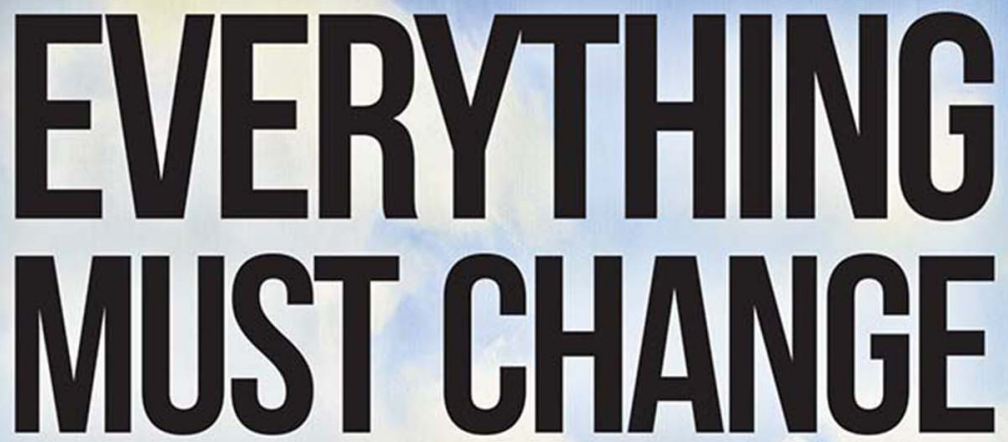

\title{
PHILOSOPHICAL LESSONS FROM LOCKDOWN
}

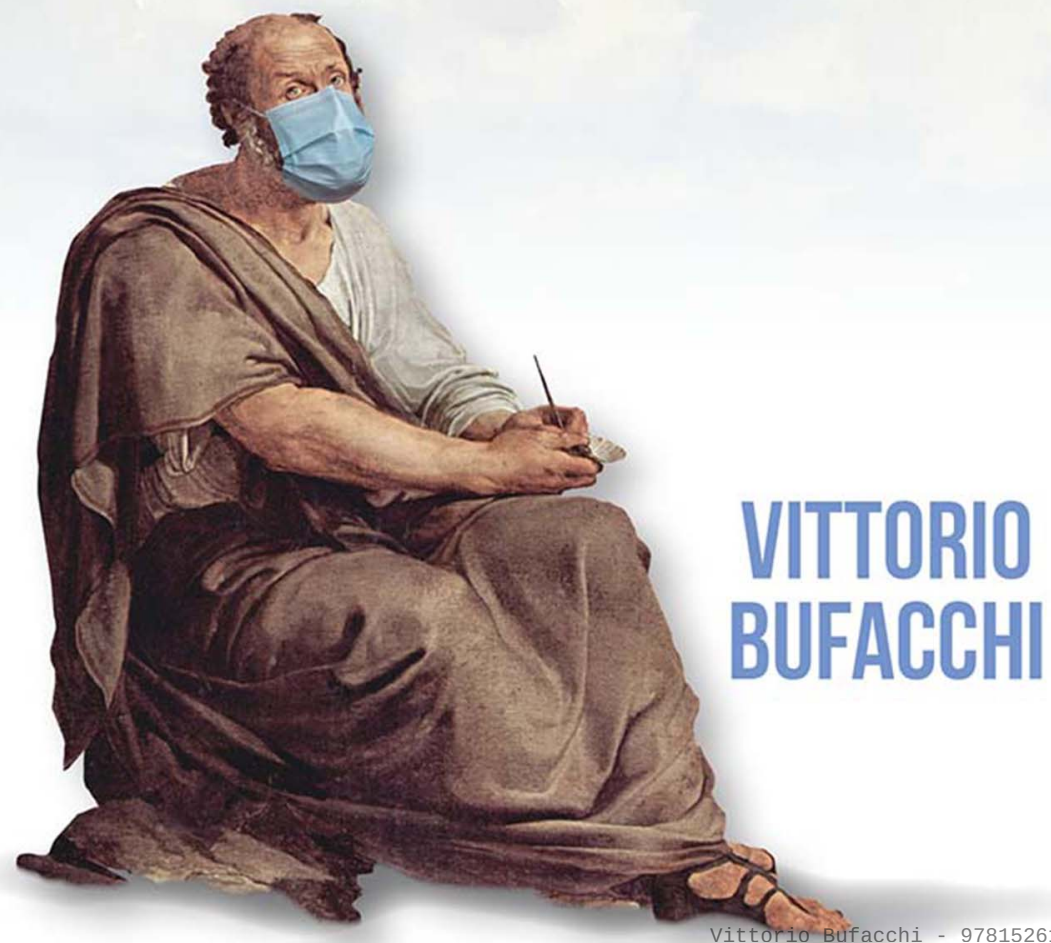

Downloaded from manchesterhive.com at 04/26/2023 09:31:29AM 


\section{Everything must change}

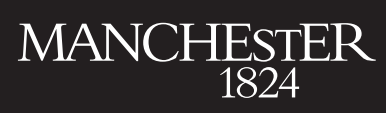

Manchester University Press 
Vittorio Bufacchi - 9781526158789

Downloaded from manchesterhive.com at 04/26/2023 09:31:29AM 


\section{Everything \\ must change \\ Philosophical lessons from \\ lockdown}

Vittorio Bufacchi

Manchester University Press 
Copyright () Vittorio Bufacchi 202 I

The right of Vittorio Bufacchi to be identified as the author of this work has been asserted by them in accordance with the Copyright, Designs and Patents Act 1988.

Published by Manchester University Press

Altrincham Street, Manchester Mi 7JA

www.manchesteruniversitypress.co.uk

British Library Cataloguing-in-Publication Data

A catalogue record for this book is available from the British Library

ISBN 978 I 526I 58772 hardback

First published 202I

The publisher has no responsibility for the persistence or accuracy of URLs for any external or third-party internet websites referred to in this book, and does not guarantee that any content on such websites is, or will remain, accurate or appropriate.

Typeset by

Servis Filmsetting Ltd, Stockport, Cheshire 